\title{
Quando a ciência está na UTI, quem perde é a sociedade
}

\author{
Bárbara Coelho Neves ${ }^{1}$ \\ Denise Braga Sampaio ${ }^{2}$
}

Caros/as leitores/as,

Le Coadic (2004) $)^{3}$ afirmara que a informação é seiva da ciência, entendendo que o processo geracional do fazer ciência é enredado no trânsito deste insumo. Insumo compreendido nas ações de acesso, uso e disseminação. No entanto, há outro fator que tanto Ihes é constituinte e por essas duas, constituída, a verdade. Conforme Sampaio; Oliveira e Olegário 4 , a informação é, também, matéria-prima da verdade e a verdade, o objetivo da ciência, cujo alcance, sempre aproximativo, se dá por meio do método e do rigor científico, amparado pelas tecnologias. As tecnologias, por sua vez, funcionam como próteses dos sentidos, na medida em que ampliam e potencializam suas capacidades.

Tudo parece harmônico, entre a ciência, a informação, as tecnologias e a verdade, no entanto, não é. Conforme Bourdieu ${ }^{5}$, à ciência, compreende um campo, com seus atores sociais em interação intra e intercampo. Ambas as interações, se dão tanto em meio à disputa, como às parcerias. É neste sentido que Bourdieu 6 evidencia o equívoco, talvez inocência, de Merton, que a entendia como universal, comunalista, de interesse desinteressado e enredada em um ceticismo organizado. Em um primeiro momento, até parece ser. Mas ao discutirmos, por exemplo, o epistemicídio negro e indígena no Brasil, podemos mesmo falar em uma ciência universal? Em que medida a ciência é, efetivamente, comum a todos? A realidade brasileira caminha em uma direção contrária a este entendimento, afinal, o ano de 2019 é marcado por uma perda orçamentária de aproximadamente $25 \%$ para educação (equivamente a $\mathrm{R} \$ 5,839$ bilhões ${ }^{7}$, berço da ciência. A Coordenação de Aperfeiçoamento de Pessoal de Nível Superior (CAPES), por exemplo, amarga a supressão orçamentária fruto das políticas de contingência do atual governo. Estes cortes reverberam também na conceção de bolsas a alunos de graduação e pósgraduação, prejudicando as pesquisas ${ }^{8}$ no âmbito das Instituições de Ensino Superior. Estas ações foram capitaneadas a partir da aprovação, no ano de 2016, da Emenda Constitucional no 95 (EC do Teto de gastos). Conforme a redação de seu Artigo 106, "Fica instituído o Novo Regime Fiscal no âmbito dos Orçamentos Fiscal e da Seguridade Social da União", em outras palavras, tal dispositivo serve, em teoria, para a redução de gastos do Estado, isso inclui áreas essenciais tais como saúde e educação, impactando negativamente, como já visto, no investimento e subsídio da pesquisa brasileira, mas também,

\footnotetext{
${ }^{1}$ Editora deste número. Professora do Instituto de Ciência da Informação da Universidade Federal da Bahia (DDI-UFBA). Pesquisadora Lider do LTI Digital. Doutora em Educação. Pós-doutora em Ciência da Informação.

2 Editora deste número. Professora do Departamento de Documentação e Informação da Universidade Federal da Bahia (DDI-UFBA). Vicelider do LTI Digital. Mestre em Ciência da Informação.

${ }^{3}$ LE COADIC, Y. A ciência da informação. Brasília: Briquet de Lemos, 2004.

${ }^{4}$ SAMPAIO, Denise Braga; OLIVEIRA, Henry Poncio de. OLEGÁRIO, Maria da Luz. Hipertrofia da informação sob a ótica dos conceitos de verdade e pós-verdade. Inf. Pauta, Fortaleza, CE, v. 4, n. especial, nov. 2019. Disponível em: http://periodicos.ufc.br/informacaoempauta/article/view/42597/99530. Acesso em: 9 jul. 2020.

${ }^{5}$ BOURDIEU, Pierre. Os usos da ciência: por uma sociologia clínica do campo científico. São Paulo: Unesp, 2004.

${ }^{6}$ Ibid.

7 Ver mais em: https://www.andes.org.br/conteudos/noticia/orcamento-da-educacao-sofre-corte-de-r-5-83-bilhoes1. Acesso em: 13 jul. 2020.

${ }^{8}$ Ver mais em: https://www.unifal-mg.edu.br/portal/2019/04/15/corte-de-quase-r-6-bilhoes-da-educacao-inviabiliza-investimentos-eprejudica-ensino-e-pesquisa-no-brasil-saiba-quais-sao-os-impactos-diretos-na-unifal-mg/. Acesso em: 13 jul. 2020.
} 
na saúde, especialmente no Sistema Único de Saúde (SUS), manobra bastante perigosa, que reverbera no contexto pandêmico de 2020. Diga-se de passagem, asseverado pelas ausências e trocas sucessivas de ministro nas duas pastas ministeriais (Ministério da Saúde e Ministério da Educação). No entanto, estas duas áreas caminham, apesar das dificuldades.

É preciso destacar que, até o ano de $2018,60 \%$ de toda a produção acadêmica nacional estava sob a tutela de quinze universidades públicas ${ }^{9}$. Isso significa dizer que tanto o corpo docente, como o corpo discente e técnico destas e das demais universidades públicas, mesmo em meio às dificuldades orçamentárias, especialmente empreendidas de 2016 em diante, continuaram a produzir. Em meados de novembro de 2019, surge a primeira infecção pelo então desconhecido Sars-CoV-2 (Covid-19), causada pelo coronavírus, na província de Wuvan (China). De lá para cá, o que parecia ser uma doença respiratória viral local, espalhou-se pelo mundo, passando à categoria de pandemia, em poucos meses. Foi então que o mundo 'parou'. A Organização Mundial de Saúde (OMS) passa a recomendar o isolamento social e uso de Equipamentos de Proteção Individual (EPI) como forma de desacelerar o contágio do coronavírus. Em termos globais, até o fechamento deste editorial, foram infectadas 12.311 .751 pessoas, destas, 7.155 .936 se recuperaram, enquanto 554.883 vieram a óbito ${ }^{10}$. O Brasil, que chegou à marca de um milhão de mortos no dia 19 de junho de $2020^{11}$, atualmente, é o segundo país em número de infectados e mortos, atrás apenas dos Estados Unidos (EUA) ${ }^{12}$. No entanto, permitam-nos a correção, o mundo não parou com o isolamento. A alta taxa de infecção, no país, é inegável, mas é inegável também o esforço contínuo dos estados e municípios brasileiros, bem como dos profissionais da Saúde e dos setores de Ciência, Tecnologia, das múltiplas formas e possibilidades de expressão por meio da arte, dos trabalhadores e trabalhadoras que tiveram de continuar a desempenhar serviços essenciais e daqueles que se reinventaram com a pandemia, a partir do trabalho remoto. O resultado disso é de 1.152.467 curados, uma curva de contaminação cuja ascenção fez-se menor que a esperada, enquanto houve o cumprimento do isolamento e adoção das medidas preventivas, tais como higienização constante e uso dos EPI, famosos entre os profissionais da saúde, mas somente há pouco, conhecidos por nós.

Como verão nas páginas digitais deste dossiê, quando a ciência caminhava às cegas, e fomos acometidos pela Gripe Espanhola (1918-1920), a recomendação era muito dista da que hoje é empreendida, especialmente conforme a Organização Mundial da Saúde, criada em 1948. Neste ponto, havemos de concordar com Merton que o interesse desinteressado da ciência em favor da sociedade, do coletivo, fez e faz com que a nova pandemia viral, mesmo assustadoramente contagiosa, possa ser combatida com armas mais acuradas, com decisões mais próximas de um êxito efetivo. Apesar do empenho das ciências, das artes, dos serviços essenciais mediados pelas tecnologias, o processo de pós-verdade tem se mostrado um desafio a ser superado. Na direção contrária da ciência, mas igualmente mediada pelas tecnologias, a desinformação também tem pervadido espaços, amparada pelo discurso de desautorização das ciências, de descrédito das figuras docente e pesquisadora, traduzida em parcela significativa da população que não usa as mascaras por acharem-nas desnecessárias ou mesmo porque, segundo fake news circulada em redes sociais, este EPI pode conter o virus transmissor do Covid-19, por exemplo. Esta pequena ilustração nos mostra que há um terreno de disputa ${ }^{13}$ entre a autoridade científica, de que fala Bourdieu ${ }^{14}$ e Arendt $^{15}$, e o discurso negacionista e simplista fruto da pós-verdade, conforme afirma D'Ancona ${ }^{16}$.

Foi por entender a urgência de lançar um olhar atento ao cenário pandêmico que se descortina, que o Laboratório de Tecnologias Informacionais e Inclusão Sócio-digital (LTI Digital) reuniu, em caráter interinstitucional ${ }^{17}$, seus pesquisadores, a fim de traçar os quadros observáveis, à luz da Ciência da Informação, da Tecnologia e da Educação, de mudanças e estratégias sociais e governamentais neste contexto. Fruto destas observações, das pesquisas no âmbito do LTI Digital,

${ }^{9}$ ESCOBAR, Herton. 15 universidades públicas produzem $60 \%$ da ciência brasileira. Jornal da USP, Políticas Científicas, São Paulo, 5 set. 2019. Disponível em: https://jornal.usp.br/universidade/politicas-cientificas/15-universidades-publicas-produzem-60-da-ciencia-brasileira/. Acesso em: 9 jul. 2020.

${ }^{10}$ Dados de: COVID-19 Coronavirus Pandemic, WorldoMeter. Atualização de 9 de julho de 2020. Disponível em:

https://www.worldometers.info/coronavirus/. Acesso em: 9 jul. 2020.

${ }^{11}$ DANTAS, Carolina; PINHEIRO, Lara; MANZANO, Fábio. Brasil tem mais de 1 milhão de casos confirmados de coronavírus, aponta consórcio de veículos de imprensa. G1, Bem Estar, Coronavírus, 19 jun. 2020. Disponível em:

https://g1.globo.com/bemestar/coronavirus/noticia/2020/06/19/brasil-tem-mais-de-1-milhao-de-casos-confirmados-de-coronavirus-apontaconsorcio-de-veiculos-de-imprensa-veja-a-situacao-por-regioes.ghtml. Acesso em: 9 jul. 2020.

12 Op. cit.

${ }^{13}$ D'ANCONA, Matthew. Pós-verdade: a nova Guerra contra os fatos em tempos de fake news. Barueri: Farol Editorial, 2018.

${ }^{14}$ Bourdieu, 2004.

${ }^{15}$ ARENDT, H. Entre o passado e o futuro. 7. ed. São Paulo: Perspectiva, 2014.

${ }^{16}$ Op. cit.

17 IBICT, UFRN, FIOCRUZ, FBN, UFRJ, Universidad Nacional de Rosário (Argentina), UFBA, UNINASSAU, UFSCar, FAMEC, Fundação Visconde de Cairú (FVC), Associação Baiana de Medicina (ABM), IF Sertão Pernambuco - Campus Salgueiro, UFPE e UFCA. 
lançamos o Dossiê "Informação, Educação e Tecnologia em Tempos de Pandemia", em parceria com o periódico Folha de Rosto.

O referido dossiê trata de temáticas como desinformação no contexto pandêmico, nos trabalhos: "Emergência de saúde pública global por pandemia de Covid-19: desinformação, assimetria de informações e validação discursiva", que, sob a autoria de Clóvis Ricardo Montenegro de Lima, Nancy Sánchez-Tarragó, Danielle Moraes, Luiciana Grings e Mariangela Rebelo Maia discute os processos e dinâmicas informacionais em torno da emergência global de saúde pública pela pandemia de COVID19, com ênfase nas manifestações de desinformação ao redor da origem do vírus, da medida de isolamento social e dos tratamentos; "Significados composicionais de Infográficos e o combate à desinformação em tempos de Covid-19", das autoras Silvana Pereira da Silva e Jaíres Oliveira Santos, por sua vez, observa a contribuição dos infográficos no combate a proliferação de desinformação em tempos de pandemia.

No que diz respeito ao uso das mídias sociais, congregamos três trabalhos que tratam dos usos dessas plataformas sóciodigitais, a saber, "Um estudo de caso sobre a aplicabilidade dos vídeos de curtíssima duração nas mídias sociais como via de informação", das autoras Alessandra Ribeiro Assunção do Amaral e Bárbara Coelho Neves, tratando do potencial informativo de tais vídeos no município de Entre Rios (BA); "Lives da fé: as fronteiras entre a igreja e a comunicação virtual em tempo de isolamento social" de autoria de Deyse Luciano de Jesus Santos e Ludimila Carneiro Albuquerque, descortina como tem se posicionado, os fiéis, em relação a participação de cultos no ambiente virtual. Handherson Leyltton Costa Damasceno, autor de "Memes e narrativas em tempos de pandemia da Covid-19: um estudo analítico", se debruça sobre as narrativas meméticas no Facebook, com vistas a identificar os principais temas que emergem dos memes, uma vez que, conforme o próprio autor, tais memes são narrativas carregadas de humor, acidez, ironia, mas também uma possibilidade de alívio das tensões cotidianas, especialmente no context atípico em que vivemos atualmente. Ainda tratando da temática das redes sociais em tempos de pandemia, "As Dinâmicas Informacionais do Conteúdo Publicado pelos Governos do Ceará, do Maranhão e de Pernambuco e as Relações com as Estatísticas por Coronavírus", sob autoria de Denise Braga Sampaio, Maria Cleide Rodrigues Bernardino, Marcela Lino da Silva e Phelipe Rafael Alves de Menezes, buscou identificar a dinâmica informacional dos perfis oficiais de governos dos estados do Nordeste do Brasil - Ceará, Maranhão e Pernambuco - quanto à disseminação de informações durante a pandemia da Covid-19.

Por fim, associando o momento hodierno em que nos encontramos com as tecnologias para o combate ao Coronavírus, apresentamos, neste Dossiê, os trabalhos "Metodologias, Ferramentas e Aplicações da Inteligência Artificial nas Diferentes Linhas do Combate ao (Covid-19)", de Bárbara Coelho Neves, que trata do uso da IA no contexto da informação em saúde. Já a associação entre as tecnologias e educação podem ser verificadas em "Covid-19, Tecnologia Digital e Educação: reflexões sobre a suspensão das aulas no contexto das escolas e creches comunitárias do Município de Camaçari/Ba", sob autoria de Raquel Alves Sobrinho, Jurandir de Almeida Araújo e Bárbara Coelho Neves; "TIC para manutenção dos estudos em período de pandemia na Universidade Federal da Bahia", de Monaliza Gomes da Conceição e Ucineide Rodrigues Rocha Moreira e "O Uso das Plataformas Digitais pelas IES no Contexto de Afastamento Social pela Covid-19", sob autoria de Camila Bahia Goés e Glauber Cassiano. Estes estudos mostram como os níveis básico e superior da educação estão preocupados em reinventar-se no momento de isolamento social em que nos encontramos e como as tecnologias podem tornar-se ferramentas facilitadoras nesse trânsito para o trabalho remoto, sem esquecer, no entanto, que há, na realidade brasileira, uma disparidade entre inforricos e infopobres, portanto, o desafio não está somente no uso, mas acesso destas tecnologias e como este uso pode se dar.

É neste sentido que, conforme apontam Levitsky e Ziblatti ${ }^{18}$, precisamos estar atentos aos movimentos que buscam enredar as instituições na perspectiva do controle social e da perseguição às autoridades científicas. Instituições, a exemplo das universidades, têm sido alvos de uma autocracia eleita que pretende manter a ciência com cuidados reduzidos na UTI. Contudo, ironicamente, é exatamente neste momento - quando as universidades, a pesquisa científica e seus centros e laboratórios estão sendo levados ao seu limite vital -, que se tem a visibilidade de como estes espaços e territórios do conhecimento são necessários para a manutenção da vida e essenciais para responder às situações, como a pandemia em que a sociedade neste momento se encontra.

18 LEVITSKY, S.; ZIBLATTI, D. Como as democracias morrem. Tradução Renato Águiar. Rio de Janeiro: Zahar, 2018. 
O LTI Digital, através das suas linhas de pesquisa: "TIC, Comunicação Científica e Ambientes Informacionais Digitais"; "Redes/Mídias Sociais, Marketing Digital e Computação Cognitiva"; "Metodologias Ativas de Ensino para Arquivologia, Biblioteconomia, Museologia e Ciência da Informação"; "Inclusão Sociodigital, Políticas Públicas de Educação e Informação voltada para cultura digital" e "Acessibilidade, Tecnologias Assistivas e Inclusão" coaduna com as pesquisas ora apresentadas neste dossiê e entende que, conforme o título desse editorial, "quando a ciência está na UTI quem perde é a sociedade".

O LTI Ditigital vinculado ao Instituto de Ciência da Informação da Universidade Federal da Bahia (ICI/UFBA) está abrigado no Portal: https://tidigital.ufba.br/ através de suas líderes, Profa. Bárbara Coelho Neves e Profa. Denise Braga Sampaio, agradece à revista Folha de Rosto: Revista de Biblioteconomia e Ciência da Informação pela oportunidade de contribuir para a Ciência brasileira através do Dossiê "Informação, Educação e Tecnologia em Tempos de Pandemia" e convida a todas, todos e todes à leitura.

Boa leitura!

As editoras convidadas 